\title{
Joris Boonen
}

Eva Falk Pedersen

Marc Hooghe

\section{The effect of political sophistication and party identification on voter-party congruence. A comparative analysis of 30 countries}

\author{
Journal of Elections, Public Opinion, and Parties, accepted.
}

FINAL AUTHOR MANUSCRIPT

\begin{abstract}
Partisanship and cognitive mobilization are generally seen as independent and counterbalancing influences on vote choice. While the former is typically regarded as a shortcut, reducing the need for close ideological congruence with one's preferred party, the latter is associated with increasing levels of political sophistication and the importance of ideological proximity in voter decision-making. This paper tests the strength of these arguments in comparative perspective using data from Wave 3 of the Comparative Study of Electoral Systems (CSES). Our results show that in general higher levels of political sophistication are associated with higher levels of voter-party ideological congruence and that a strong party identification reduces this proximity. For voters with both high levels of sophistication and strong partisanship, however, congruence remains high. In a second step we examine whether these relationships are affected by the complexity of the party environment. Our findings show that party system size has no effect on levels of ideological congruence at the individual level, and this holds for different levels of voter sophistication. We conclude that for the most part voter sophistication and party identification are best seen as counter-weights in determining vote choice
\end{abstract}

Keywords: Congruent voting, political sophistication, party identification, left-right identification, effective number of parties, CSES 


\section{Introduction}

Several decades of empirical research have made it clear that voting is becoming a more individualized process and voters' choices are increasingly dependent on short-term issues and campaign related considerations rather than longer term party loyalties. (Dalton, 1984, 1996; Franklin, 1992; Van der Brug, 2010). These developments have been interpreted in contrasting ways with some observers voicing concern about their implications for democratic legitimacy given the role of parties as a key linkage mechanism between citizens and the state. When voters feel close to a political party then they are arguably more likely to feel connected to the political system as a whole (Hooghe \& Kern, 2015). Furthermore, a party identification can serve as a cognitive heuristic that helps citizens to make sense of the complex political world and guides their voting decisions (Lau \& Redlawsk, 2001). Other scholars have taken a more positive view of such developments, arguing that the shift away from partisan loyalties has been driven by increased information availability and rising levels of educational attainment. Citizens are now regarded as more 'cognitively mobilized' and able to orient themselves independently in the political world, as opposed to following a party 'auto-cue' (Dalton, 1984; Downs, 1957). This more critical approach to vote choice is seen as enhancing democratic representation by increasing the extent of ideological congruence or fit between voters and their party of choice. (Dalton 2013; Carmines \& Stimson, 1980). In addition increased perceptions of congruence between voters and parties may in fact increase incentives to turnout, particularly for those located at the extremes of the political spectrum as recent research has shown (Lefkofridi, Giger and Gallego, 2013).

The process of partisan dealignment has important and contested implications for the substantive representation of citizens' preferences, as expressed through their voting behavior. It is our purpose in this paper to seek to address and resolve this debate through a more 
comprehensive and precise examination of the relationship between the three core variables in question - namely the strength of party identification, levels of cognitive mobilization and voter-party ideological congruence. Our starting assumption, following the premise of the cognitive mobilization theorists, is that as levels of party identification decrease, levels of ideological congruence between individual voters and parties will increase. Our second and corollary assumption is that increases in levels of voter sophistication will be associated with higher levels of ideological congruence (Lau, Patel, Fahmy \& Kaufman, 2013). Cognitive mobilization should strengthen the capacity of citizens to seek and process the information they need to arrive at a well-considered vote choice. Finally, we introduce a layer of systemic variance to understand whether political context and particularly the size of the party system moderates these relationships. In those systems were fewer parties compete, the cognitive requirements in deciding who to vote for are clearly lower for without a strong partisan attachment. Conversely a more complex multi-party systems where more choices are available means that such voters will find it more difficult to judge the political party that is closest to their own preferences We thus develop and test a third assumption that levels of cognitive mobilization play a stronger role in determining vote choice in complex multi-party systems.

In the following section, we briefly review the literature on substantive political representation and formulate hypotheses that will be tested with data from the Comparative Study of Electoral Systems (CSES).

\section{Voter-party congruence}

It should be noted that in examining broad levels of voter-party ideological congruence we are stepping back from the more policy-focused literature on congruence that has emerged in recent years studies (Holmberg 1999; Blais \& Bodet 2006; Norris 2011). This is a rich body of work that has yielded important insights into the extent of voter-party alignment. The core foci of 
these studies, however, is on the outcomes or end products of the policy making process and whether these are reflective of citizens preferences i.e. whether the system is functioning effectively to deliver political representation in terms of specific outputs (Rosema, Denters \& Aarts 2010). Our interest in this paper, however, lies in the earlier stages of the representation process, i.e. at the point of electoral choice and whether voters actually end up voting for a party that takes the same policy positions as they do.

In conceptual and methodological terms, studies of voter-party congruence continue to be inspired by the seminal work of Miller and Stokes (1963). These authors examined the influence of constituency opinion on the U.S. Congress and triggered the growth of a new field of inquiry into substantive representation (Powell, 2004). Within this literature congruence was typically understood as a many-to-many phenomenon whereby policy outcomes were compared with citizen preferences. (Golder \& Stramski, 2010; Powell \& Vanberg, 2000; Giger and Lefkofridi, 2013). There are, however, other ways of understanding the concept of ideological congruence as Golder and Stramski (2010) make clear. These include the notion of one-to-one congruence, i.e., the absolute distance between a citizen and his/her representative; and (2) many-to-one congruence, i.e., the distance between a group of voters and their elected official In this study, given the actors we are focusing on, we opt for a one-to-many understanding of congruence whereby we examine the extent to which individual voters are ideologically linked to their preferred party as a whole rather than to policy aggregates or individual representatives. As well as forming our core relationship of interest, studying congruence in terms of voter-party linkage has a number of advantages over studies that focus on voter -policy maker links, particularly in comparative context. Given that most countries do not operate single member districts but instead base electoral competition on multi-member districts, the connection between voter and policy maker is likely to be blurred post-election. Furthermore policy making in such systems is invariably based on compromise between 
different parties, which further reduces the visibility of the link between voters and policy decisions.

As well as developing the dimensions of the concept of voter-party congruence, we also seek to refine its operationalization and measurement. Our starting point is Lau and Redlawsk's (1997) influential work on the "quality of democratic representation" which investigates the ability of individuals to vote 'correctly' i.e. to choose the party that is closest to their ideological preferences. They argue that the health of democracy should not be judged simply on turnout but also on the extent of correct voting that takes place (Lau, Patel, Fahmy, \& Kaufman, 2013). To measure their core concept of interest - correct voting - they use a basic binary measure which registers simply whether a voter has voted for the party that is ideologically closest to them? If yes, then they voted correctly, if not, then they voted incorrectly. While we accept this can be seen as a valid means of assessing correct voting it is not necessarily a measure of closeness to one's party of choice in that it fails to register the actual distance or proximity between voters and their preferred party. When a voter votes for the 'correct' party, we still in fact do not know whether this party is ideologically close to him or her, or whether this party is simply the best available option within a given party system. Using ideological distance as our dependent variable rather than a simple binary measure of correct / incorrect allows us calibrate more precisely the extent of (in)correct or (in)congruent voting occurring within the electorate and thereby undertake a more robust test of our hypotheses.

\section{Political sophistication, party identification and ideological congruence}

One of the more obvious determinants of whether citizens vote for a party that is ideologically close to them is the level of political sophistication. The reasoning here is that those who are 
well informed and interested in politics will find it easier to identify the party that matches best with their ideological preferences. For the operationalization of political sophistication, the level of political knowledge is the most important indicator (Lachat, 2007; Lau et al., 2013). Scholars studying the development of political knowledge among citizens have argued that political knowledge is the key to make vote decisions in a well-considered way (Delli Carpini \& Keeter, 1996; Galston, 2001; Gibson \& Hamilton, 2013; Grönlund \& Milner, 2006). Therefore, low levels of political knowledge could lead to concerns about the quality of democratic representation (Fraile, 2010; Howe, 2010).

Empirical studies of the relation between political sophistication and congruence have generally pointed to a positive relationship. Lau et al. (2013) found that voters with a higher level of political sophistication are better able to vote for the party that is closest to them ideologically. Similarly, Singh (2010) shows that individuals with a higher level of education will be more likely to vote for the most proximate party. However, a recent study of ideological congruence between candidates and voters in the U.S. House elections (Simas, 2013), found no significant relation was found between political knowledge and proximity voting. This was explained by a stronger elite polarization in the U.S. system, with as a result that even voters with low levels of political knowledge are still able to identify the party that is closest to their own preferences. Based on the weight of evidence to date, therefore, we follow the theoretical assumption citizens with higher levels of political sophistication will express a vote choice that is closer to their ideological preference. We articulate this expectation in our first hypothesis:

H1: Ideological congruence between voters and their preferred party is stronger for citizens with a higher level of political sophistication.

A second individual characteristic that is associated with voter-party congruence is party identification. Following the original definition developed the Michigan school, party identification is seen as an individual's affective orientation to a group-object in his or her 
environment, in this case a political party (Campbell, Converse, Miller, \& Stokes, 1960, p. 121), In electoral research, party identification has traditionally been found to be a strong determinant of vote choice (Dalton, Farrell, \& McAllister, 2011). Despite the strong linkage it signals between voter and party, however, the affective rather than cognitive nature of the construct means that it does not necessarily imply or require a high degree of ideological congruence between the two. According to the Campbell et al. perspective, party loyalty is a fixed trait that serves as a useful cognitive heuristic or shortcut to voters in their political decision making (Lau, Andersen, \& Redlawsk, 2008). Of course this doesn't preclude party id serving as a stimulus to increased congruence, since identifiers are presumed to be highly attuned to the cues and information from their party and to actively use this to make sense of the complex political reality (Johnston, 2006). Recent work by Merrill and al. (2001) has shown for example that party identifiers have a more accurate perception of their party than those voters that do not identify with that party.

Over the past decades the central role of party identification in driving vote choice has come under increasing scrutiny as levels of stable partisanship have declined (Dalton \& Wattenberg, 2002; 2000). Such changes have prompted a revisionist approach to the concept which views it as a more 'movable' phenomenon that is subject to change based on retrospective evaluations of parties' performance (Carsey \& Layman, 2006; Fiorina, 2002). In its place, short term factors have risen to the fore, making voter decisions a more individualized process. (Achen, 2002; Fiorina, 2002; Franklin, 1984 Carmines \& Stimson, 1980). While some of these cues are based on reactions to candidates' personalities, images and short-term campaign events (McAllister, 2007; Pierce, 1993) these trends have also been accompanied by rising voter educational levels and the growth of access to political information. For Dalton (1984) this has prompted a wider process of cognitive mobilization occurring in advanced industrial societies that has increased the role of political sophistication as a driver of voter 
decision. This more discriminant understanding of party positions is seen as leading to closer voter-party ideological alignment.

Thus, while there is a case for partisan identification leading to higher levels of voterparty ideological congruence, the more recent theoretical and empirical evidence would suggests that affective identification with political parties is increasingly giving way to more individualized voting motives. While the cognitive demands of these motives vary, the overall result is one in which voters effectively re-evaluate and update their view of political parties during each election cycle and make the choice that best matches their preferences. Following this line of reasoning, therefore, we expect, ceteris paribus, to see a negative relationship between the strength of party identification and levels of voter-party ideological congruence. This should hold most strongly for those with low levels of political knowledge.

H2: Ideological congruence between voters and their preferred party is weaker among citizens with a stronger partisan identification.

It is apparent from the expression of $\mathrm{H} 1$ and $\mathrm{H} 2$ that we are presenting political sophistication and partisanship as essentially counter-veiling or cross-cutting forces. As one is rising in prominence as a driver of vote choice, the other is receding. While this follows the logic of much of the extant literature, as we have shown, this does not mean they operate in an entirely inverse manner to one another. There are of course cases of overlap, i.e. where individuals have high levels of sophistication and are also strong partisans. In such cases what are our expectations? Dalton (2014) offers some help in this regard when he distinguishes 'ritual partisans' from 'cognitive partisans'. While ritual partisans have a strong party identity they score low on cognitive mobilization. Cognitive partisans, however, combine this party identity with a high level of cognitive mobilization: "[Cognitive partisans] are committed to a political party, but this commitment is typically accompanied by knowledge about contemporary politics" (Dalton, 2014, pp. 140). This is an important qualification to H2 in that it indicates 
that sophistication has a moderating effect on the impact of party id such that cognitive partisans are likely to be among the most aware of all voters of the ideological position of the party they support. To capture this interactive effect, an additional hypothesis $(\mathrm{H} 2 \mathrm{a})$ is formulated and tested:

H2a: The relation between partisan identification and ideological congruence is moderated by a voter's level of political sophistication.

\section{The party system}

Our expectations set out in the first three hypotheses operate at the individual level. However, we can expect these individual level relationships to be responsive to the wider political context (Blais \& Bodet, 2006; Holmberg, 1999; Wessels, 1999), and particularly the dimensions of the party system. Here, a very plausible starting logic would suggest that a larger number of parties will increase congruence by increasing the likelihood that voters will find a party that matches to their preferences. Dalton (1985) has for example shown that proportional electoral systems - which are typically associated with multi-party systems - are more accurate in representing voters in terms of policy preferences. He develops the logic of increased choice to argue that in plurality-based electoral systems, parties will follow a moderate line to appeal to as many voters as possible. In proportional systems parties have an incentive not to move too far from their voters. His subsequent analysis of the correspondence between voters and elites supports his argument further by showing the number of parties to be positively correlated with this congruence. More recent empirical study has also supported such claims by demonstrating that countries with proportional electoral rules are more likely to have legislatures congruent with the ideological preferences of the citizenry than countries with majoritarian systems (Golder \& Stramski, 2010).

However, when looking at vote choices at the individual level it is important to keep in mind that the ability to make such reasoned choices varies based on levels of cognitive skills. 
When only two viable options are presented to the voter then arguably less knowledge is needed to identify the party that is closest to one's position. In bigger party systems, however, this would be likely to require a higher degree of cognitive skills. Such a premise is supported by the work of Klingemann and Wessels (2009) who look at the impact of macro-contexts on individual-level vote choice and show that when confronted with a large number of parties, voters are forced to look for ways to reduce the complexity. It is the recent studies of Lau et al. (2013), however, that are most relevant in this regard in that they explicitly test the idea that a larger number of parties increases the difficulty voters face in finding a party to match their preferences. Their analysis of comparative survey evidence finds a negative relationship exists between the effective number of electoral parties (ENEP, see Laakso \& Taagepera, 1979) and the ability of individuals to "vote correctly". More specifically they show that with two alternatives on offer, 79 percent of the respondents cast a vote in line with their preferences. However when nine alternatives were on offer this drops to less than 57 percent choosing correctly (Lau et al., 2013 pp. 16). They conclude that a larger number of parties seems to reduce the number of "correct votes". Extending this finding to our study we would argue that the importance or weight of political sophistication in determining vote choice will vary according to the party system context. In particular it will be more important in party systems with a larger number of parties. This leads to our third hypothesis:

H3: The impact of political sophistication on voter-party ideological congruence is stronger in complex multi-party systems.

\section{Data and methods}

\section{Data}

In order to verify our hypothesis on the importance of the complexity of the party system on ideological voter-party congruence, we need comparative data. Second, to build the dependent 
variable, congruence, we need data on respondents' self-placement on a left-right scale and the location of parties on that same scale. We opted for the use of a clear and one-dimensional measure for congruence, to optimize the comparability between the countries. Although it has the limitation of being an abstract and general measure of ideology, and some authors suggest that political attitudes are structured by more than one dimension (Lachat, 2009; Van Spanje \& Van Der Brug, 2007), left-right identification still is the only available tool that can effectively align political issues and define the space of political competition in a straightforward manner. The most important advantage of this approach is that we can create a clear measure for congruence that can be compared across countries. Third, we need reliable measures for the other main independent variables: political sophistication and party identification.

The third module of the Comparative Study of Electoral Systems (CSES) meets these three criteria. CSES is a large-scale quantitative data project and it is a collaboration of academic election study teams throughout the world. The data are gathered in national postelection surveys and are freely available in a merged dataset. One of the main specific advantages of the CSES for our research questions is that the self-placement and the placement of parties on the left-right scale are located at the same point temporally (Golder \& Stramski, 2010).

Some countries have been excluded from the dataset. Relying on the Freedom House ratings, we have dropped countries that are not considered to have free and fair elections such as Belarus, the Philippines and Thailand. Taiwan also has had to be excluded because the effective number of electoral parties and disproportionality measure were not available. This leaves us with 39 legislative elections to study in 30 different countries. The total number of respondents for this specific data selection is 36,230 .

\section{Dependent variable: congruence}


In order to capture the absolute distance on a left-right scale between voters and parties, we calculated the absolute difference between the experts' placement of the party the respondents voted for and their own self-placement (Powell 2004) ${ }^{1}$. The result is then subtracted from the maximum distance one could have (10) in order to arrive at a congruence scale where higher scores indeed a stronger degree of congruence. Think of a leftist voter who indicates that $\mathrm{s} / \mathrm{he}$ is 'a 2' on the left-right scale, but votes for a party which scores an 9 on this scale. The absolute distance between himself and this party is $[9-2]=7$. In our congruence measure, we subtract this number from the scale maximum (10) to come to a congruence score of $[10-7]=3$. This way, a voter that places himself on the exact same position as the party he votes for, will have a 10 on our congruence scale.

The mean congruence $\mathbf{C}$ is calculated as follows:

$$
C=\frac{1}{n} \sum_{i=1}^{n_{i j}}\left(10-\left|v_{i j}-p_{j}\right|\right)
$$

In which $\mathbf{v}_{\mathbf{i j}}$ is the $0-10$ score on the left-right identification scale of voter $i$ in country $j$, $\mathbf{p}_{\mathbf{j}}$ is the expert placement of the left-right identification of the voter's preferred party in country $j$, and $\mathbf{n}$ is the sample size. In the analyses below, this dependent variable has been rescaled to range from 0 to 1 in order to ease interpretation.

In Table 1, we present the congruence means by election year. The 2011 Estonian election is the election for which the distance between voters and the party they voted for is the largest. In Estonia, in 2011, 40\% of the citizens did not vote for the party that is closest to their left-right preference. The next two countries with the lowest congruence levels are South Africa (2009)

\footnotetext{
${ }^{1}$ We have also tested the measure by using the median placement of the parties given by the respondents as Blais and Bodet (2006) suggest, but this did not lead to any substantial differences in the analyses.
} 
and the United States (2008). We find most of the Scandinavian countries at the highest congruence end.

\section{-- Table 1 about here -}

\section{Independent variables}

Our two main independent variables on the individual-level are political sophistication and party identification. For the conceptualization of political sophistication, a number of different indicators have been used, such as political interest, educational level, exposure to political information and political knowledge (Dassonneville, 2012). In our conceptualization, we follow the argument set forward by Lachat (2007), among others, that political knowledge is the most valuable indicator: "Actually, a large body of literature does exist and it shows that this is the best single indicator of a person's level of political sophistication" (Lachat, 2007, p. 57). For political knowledge, CSES comprises three questions adapted to each country-year election. The merged variable is constructed ranging from 0 (no right answers) to 3 (all answers right). The possibility of measuring political knowledge across countries in a consistent way has been the subject of numerous debates over the past years. The CSES team has made a consistent effort to comparatively assess political knowledge. The political knowledge questions are not just a translation of standard items (as is the case for most other survey measures), but they are adapted to each national context. Milner and Grönlund (2006) have emphasized the limitations of the cross-national equivalence in political knowledge questions, but simultaneously acknowledge the efforts made by CSES to achieve comparability. CSES has instructed all national research teams to formulate three political information questions in such a manner that one question will be answered correctly by two thirds, another one by half and a last one by one third of the respondents. As an additional test in this paper, we tested the correlation between 
political knowledge and educational attainment in the different election studies, and our results indeed indicate that there is a strong relation between political knowledge and educational attainment $\left(0.198^{* * *}\right)$, enhancing our confidence in the validity of this scale.

Our second independent variable, party identification is also coded as a categorical variable with 3 categories: respondents without a party identification and weak identifiers are coded 0 , respondents who indicated that they have a party identification and felt somewhat close to a political party are coded 0.5 and the strong identifiers, who feel very close to the party are coded $1^{2}$. The non-identifiers (0) are used as a reference category in the analyses. At the individual-level we also control for age (continuous variable) and gender (women are coded 1). To test our expectation $(\mathrm{H} 2 \mathrm{~b})$ that the effect of party identification is moderated by political sophistication, we also include an interaction term between both. For this interaction term, party identification is included as an ordinal variable (1-4). Finally, we control for the level of formal education, which is coded in four categories: no or only a primary education $(0$, ref.), secondary education (1), college education (2) and university education and higher (3).

At the system level our core independent variable of interest - the complexity of the party system - is captured by the effective number of electoral parties (Laakso \& Taagepera, 1979). ${ }^{3}$ We also include a measure of the disproportionality of the party system to control for the extent to which majoritarian/plurality electoral rules may be distorting or enhancing the impact of voter sophistication and partisan identification. We expect that more proportional party systems are more likely to be more complex party systems, because of the more nuanced

\footnotetext{
${ }^{2}$ We have also used an alternative coding, in which all categories of the scale were included separately on a 1-4-scale, but this did not alter the results. Since it is more rigorous to not consider weak identifiers, we have decided to use this coding in the final model.

${ }^{3}$ In two additional tests on the country level, we included a variable for years of democracy (ranging from 7 to 199 years) and a dummy variable for whether the country has been a postcommunist democracy or not. These two variables did not alter the results in any way: the variables are not significant and the ICC does not vary significantly.
} 
nature of the electoral competition. Disproportional systems (e.g. the UK system) generate competitive advantages for the larger parties, but consequently also create a situation in which the competition is more strongly focused on a few major parties and thus a few major ideological contrasts.

We follow the suggestion from Blais and Aarts (2006) not to include dummies for party systems, but measures for the effective number of electoral parties and disproportionality from the previous election. "Disproportionality can be conceptualized as a summary measure that takes into account both the electoral formula and district magnitude” (Blais \& Aarts, 2006, p. 188). We take these ratings from the election that comes before the election measured in the CSES. Michael Gallagher's Election Indices Dataset has been used to retrieve these indices.

Finally we include measure of party system polarization using Dalton's (2008) polarization index for the third module of the CSES. This measure is based on the median leftright placement of parties by voters, adjusted to reflect each party's vote share. Party system polarization is a direct reflection of the ideological differentiation in a political system (Dalton, 2008). In that sense, it is also an alternative indicator of the party system's complexity, as more ideological differentiation leads to a broader and more widespread set of ideological views within the party system as a whole.

Table 2 presents descriptive information for all the independent variables included in the analysis.

\section{-- Table 2 about here --}

\section{Results}

Because of the nested nature - individuals within countries - of the CSES data, and because we have both contextual and individual-level research questions, we apply multilevel regression models. Table 3 reports the results for all models. The first model presented is the null model. 
Model I incorporates the individual-level factors and Model II the additional interaction between party identification and political sophistication. In Model III we include the countryyear level factors and in the final model (IV), we added the cross-level interaction between the effective number of political parties (aggregate) and political knowledge (individual). The estimation of the null model shows an intra-class correlation coefficient (ICC) of 0.166. This coefficient suggests that context-specific differences are important. In Model I, we see that higher political knowledge is indeed linked to higher congruence. If we look at the relation with party identification, however, we see that results are mixed. For respondents who only felt somewhat close to a party, the effect is positive, but smaller compared to those that have no or a weak partisan identification. As expected, having a strong attachment to a party is negatively related to the ideological left-right congruence with this party $\left(-.109^{* * *}\right)$. However, our interaction term between party identification and political knowledge (added Model II) shows an important qualification of this result, in line with $\mathrm{H} 2 \mathrm{~b}$. Indeed, we can observe that more knowledgeable partisans can benefit from this party identification in terms of ideological voterparty congruence. The combination between both has a positive effect on the left-right congruence between voter and party.

Moving to our individual level control variables we see that the coefficient of age is negative and significant, but very close to 0 . The regression coefficient for gender suggests that men (coded 0 ) have a slightly smaller probability than women to cast a congruent vote. Finally the relation between education and congruence is positive and significant. The higher the level of education, the higher the ideological congruence between a voter and his/her preferred party.

Models III and IV add in the systemic variables. Here we are mainly interested in the effect of the effective number of electoral parties on levels of congruence, given voters' levels of political sophistication. First, in Model III, we can observe that the macro level results do not indicate that a more complex party system has a direct negative effect on ideological 
congruence. This already deviates from the earlier studies discussed above, in which the complexity of the party system affected the number of "correct votes". Next, we also find that the control for disproportionality is not significant. Levels of polarization, however, are negative and significant. As polarization increases, congruence between voters and parties decreases.

Although the number of competing electoral parties does not have a direct effect on voter-party congruence, it still remains useful to include an interaction term between political sophistication and the effective number of parties (H3), as is done in Model IV. With this additional test, we can analyze whether the effect of political sophistication is comparable across different party systems.

Even if we expect that political knowledge interacts with the number of parties in each election, we have verified the full model with a random slope for political knowledge in order to see if the variable indeed acts differently in each country. The interaction effect is negative, but extremely small (-.015). Because this negative interaction effect can be misleading and hard to interpret, we follow the suggestion to graph the interaction effect (Brambor, Clark \& Golder, 2005).

In Figure 1, the dotted line is the $95 \%$ confidence interval and the solid line represents the simulations of predictions of each cutting point between the interaction variable and congruence. As is shown in the Figure, the expected interactive effect of political knowledge and the number of parties is indeed extremely small, and we should therefore be very careful in overstating its importance. In sum, the main conclusion we can draw from this result is that the effect of political sophistication hardly differs across systems with a higher or lower level of complexity in the competition (measured with the effective number of political parties), showing no conclusive empirical evidence for $\mathrm{H} 3$. 


\section{- Figure 1 about here -}

\section{-- Table 3 about here -}

\section{Discussion}

Three main conclusions can be drawn from the current analysis. First, we find support for the idea that those voters with higher levels of sophistication i.e. who are more cognitively mobilized, exhibit a stronger degree of ideological congruence with their preferred party. Second, we find support for the general weakening effect of party identification on levels of congruence. Compared with weak or non-identifiers (independents), those with a strong party identification display a lower degree of left-right congruence with the party they vote for. There is, however, an important caveat to this conclusion in that we find a small but significant positive effect for the interaction term between party identification and political sophistication (H2a). This shows in effect that $\mathrm{H} 2$ does not hold for all voters, in that more sophisticated identifiers align ideologically with the party they vote for, even more so than independents. Finally we do not find any evidence to support the idea that the impact of political sophistication on levels of voter-party congruence is heightened under conditions of greater party system complexity (H3). Instead it appears that political sophistication is similarly important, whether the competition is dominated by two large parties, or fragmented among a dozen smaller ones. While this null effect is somewhat surprising it is perhaps not so much so when we consider the fact that levels of party system complexity overall were not significantly related to variance in the mean levels of voter-party ideological congruence. This finding clearly runs contrary to current wisdom, and we speculate on the methodological reasons and implications of this below. In substantive terms, however, we have argued the null outcome may be shielding a more sophisticated dynamic, whereby more parties are increasing the likelihood of congruence 
among individual voters, as proposed by Dalton (1985) and thereby cancelling out the negative effects of increased complexity (Blais \& Bodet, 2006) .

Contextualizing our findings within the wider literature, we argue that they carry several important implications. Firstly they provide support for the conceptualization of party identification as set out in the "American Voter" (Campbell et al., 1960). Here identification with a political party is viewed primarily as an affective orientation. While one might have a strong identification with a political party, this does not necessarily mean there is a high ideological congruence between the voter and the party. Second they suggest that those voters without a strong partisan identification tend to make more rational choices on polling day in the sense that they are choosing parties that are more congruent with their own ideological preferences. If this is the case then one could see the contemporary trends in voter dealignment to hold positive consequences for the quality of representation, as envisaged by the cognitive mobilization theorists. Of course such an outcome is still 'trumped' by the ideal scenario of increased voter sophistication and a strengthening of partisanship leading to enhanced levels of voter-party congruence. However, as the results of $\mathrm{H} 2 \mathrm{a}$ reveal, such a mix remains something of a perfect storm that is confined to a small section of the electorate.

Finally our null finding with respect to the effect of party system complexity on voterparty congruence is interesting in that it directly contradicts those reached in recent studies by Lau et al. (2013) and Singh (2010) examining the concept of 'correct voting'. Using CSES data, these authors concluded that an increase in the number of parties actualy decreased the chance that a voter voted 'correctly' i.e. chose the party ideologically "closest" to them. One obvious explanation for our contrary findings we contend lies in the more precise approach we adopt in measuring the core concept of ideological closeness. Rather than understand closeness as a binary concept which involves a voter having made a 'correct' or 'incorrect' choice based on their having voted (or not voted) for the party closest to them, we propose a more quantitative 
or scaled measure that is based on the actual distance between the voter and their party of choice. For example adopting the Lau et al (2013) method, a voter on the far left of U.S. politics would be seen to have voted just as "correctly" as one on the centre-left by choosing the Democratic Party. However, the voter-party ideological distance would likely be much greater for the former than for the latter. Our results would thus suggest the need for future studies to at least consider a more calibrated measure of voter-party congruence than current binary approaches permit. In addition, these findings should also caution us against inferring levels of ideological congruence within a given country based on the number of "correct votes" that have been cast.

A last point of methodological significance that arises from our work which future studies of the topic would do well to bear in mind is the critical value that more diverse measures of ideological congruence would add to their analysis. Here we were limited to a one dimensional measure of ideological congruence - the left-right continuum. While as noted this was a seen as important in order to capture the general rather than specific policy alignment of voters to their preferred party it is also possible that this increases the chances that more sophisticated voters score well on the congruence scale simply because they have a clearer understanding of what the concept signifies and are therefore better able to adjust their own left-right position to that of their preferred party. Use of a wider range of cleavage structures and more specific policy placement indicators adjusted to specific electoral contexts to judge voter-party congruence would provide offer a more robust test of the importance of sophistication in any future analysis 


\section{References}

Achen, C. H. (1978) Measuring Representation. American Journal of Political Science, 22(3), pp. 475-510.

Achen, C. H. (2002) Parental socialization and rational party identification. Political Behavior, 24(2), pp. 151-170.

Blais, A., \& Aarts, K. (2006) Electoral Systems and Turnout. Acta Politica, 41(2), pp. 180196.

Blais, A., \& Bodet, M. (2006) Does Proportional Representation Foster Closer Congruence Between Citizens and Policy Makers? Comparative Political Studies, 39(10), pp. 12431262.

Campbell, A., Converse, P. E., Miller, W. E., \& Stokes, D. E. (1960) The American Voter. (Chicago: University of Chicago Press).

Carmines, E. G., \& Stimson, J. A. (1980) The Two Faces of Issue Voting. American Political Science Review, 74(1), pp.78-91.

Carsey, T. M., \& Layman, G. C. (2006) Changing sides or changing minds? Party identification and policy preferences in the American electorate. American Journal of Political Science, 50(2), pp. 464-477.

Dalton, R. J. (1984) Cognitive Mobilization and Partisan Dealignment in Advanced Industrial Democracies. Journal of Politics, 46(1), pp. 264-284.

Dalton, R. J. (1985) Political Parties and Political Representation: Party Supporters and Party Elites in Nine Nations. Comparative Political Studies, 18(3), pp. 267-299.

Dalton, R. J. (1996) Political Cleavages, Issues, and Electoral Change, in: L. LeDuc, R. G. Niemi, \& P. Norris (eds.), Comparing Democracies 2. Elections and Voting in Global Perspective (Thousand Oaks: Sage), pp. 189-209.

Dalton, R. J. (2000) The Decline of Party Identifications, in: R. J. Dalton \& M. P. Wattenberg (eds.), Parties without Partisans. Political Change in Advanced Industrial Democracies (New York: Oxford University Press), pp. 19-38.

Dalton, R. J. (2014). Interpreting partisan dealignment in Germany. German Politics, 23(1-2), pp. 134-144. 
Dalton, R. J., Farrell, D. M., \& McAllister, I. (2011) Political Parties and Democratic Linkage. How Parties Organize Democracy (Oxford: Oxford University Press).

Dalton, R. J., \& Wattenberg, M. P. (eds., 2000) Parties without Partisans. Political Change in Advanced Industrial Democracies (New York: Oxford University Press).

Dassonneville, R. (2012) Electoral volatility, political sophistication, trust and efficacy: A study on changes in voter preferences during the Belgian regional elections of 2009. Acta Politica, 47(1), pp. 18-41.

Delli Carpini, M. X., \& Keeter, S. (1996) What Americans Know about Politics and Why It Matters (New Haven: Yale University Press).

Downs, A. (1957) An Economic Theory of Democracy (New York: Harper and Row).

Fiorina, M. P. (2002) Parties and Partisanship: A Forty Year Retrospective. Political Behavior, 24(2), pp. 93-115.

Fraile, M. (2010) Widening or Reducing the Knowledge Gap? Testing the Media Effects on Political Knowledge in Spain (2004-2006). International Journal of Press/Politics, 16(2), pp. 163-184.

Franklin, C. H. (1984) Issue Preferences, Socialization, and the Evolution of Party Identification. American Journal of Political Science, 28(3), pp. 459-478.

Franklin, M. N. (1992). The decline of cleavage politics, in: M. N. Franklin et al. (eds.), Electoral change: Responses to evolving social and attitudinal structures in western countries (New York: Cambridge University press), pp. 383-431.

Franklin, M. N. (2004) Voter Turnout and the Dynamics of Electoral Competition in Established Democracies since 1945. (Cambridge: Cambridge University Press).

Galston, W. A. (2001) Political knowledge, political engagement, and civic education. Annual Review of Political Science, 4, pp. 217-234.

Gibson, S., \& Hamilton, L. (2013) Knowledge, autonomy and maturity: developmental and educational concerns as rhetorical resources in adolescents' discussions regarding the age of electoral majority in England. Journal of Youth Studies, 16(1), pp. 34-53.

Giger, N., \& Lefkofridi, Z. (2014). Salience-Based Congruence Between Parties \& their Voters: The Swiss Case. Swiss Political Science Review, 20(2), pp. 287-304.

Golder, M., \& Stramski, J. (2010) Ideological Congruence and Electoral Institutions. American Journal of Political Science, 54(1), pp. 90-106. 
Grönlund, K., \& Milner, H. (2006) The Determinants of Political Knowledge in Comparative Perspective. Scandinavian Political Studies, 29(4), pp. 386-406.

Holmberg, S. (1999) Collective Policy Congruence Compared, in: P. Esaiasson, R. Herrera, S. Holmberg, R. Pierce, J. Thomassen, \& B. Wessels (eds.), Policy Representation in Western Democracies (New York: Oxford University Press), pp. 87-109.

Hooghe, M., \& Kern, A. (2015) Party membership and closeness and the development of trust in political institutions: An analysis of the European Social Survey, 2002-2010. Party Politics, 21(6), 944-956.

Howe, P. (2010) Citizens Adrift. The Democratic Disengagement of Young Canadians. (Vancouver: UBC Press).

Johnston, R. (2006) Party identification: Unmoved Mover or Sum of Preferences? Annual Review of Political Science, 9, pp. 329-351.

Klingemann, H.-D., \& Wessels, B. (2009) How Voters Cope with the Complexity of Their Political Environment, in: H.-D. Klingemann (ed.), The Comparative Study of Electoral Systems (New York: Oxford University Press), pp. 237-268.

Laakso, M., \& Taagepera, R. (1979) "Effective” Number of Parties. A Measure with Application to West Europe. Comparative Political Studies, 12(1), pp. 3-27.

Lachat, R. (2007) A Heterogeneous Electorate. Political Sophistication, predisposition strength, and the voting decision process (Baden-Baden: Nomos Verlag).

Lachat, R. (2009) Is Left-Right from Circleland? The Issue Basis of Citizens' Ideological Self-Placement. Zürich: Center for Comparative and International Studies.

Lau, R. R., Andersen, D. J., \& Redlawsk, D. P. (2008) An Exploration of Correct Voting in Recent. American Journal of Political Science, 52(2), pp. 395-411.

Lau, R. R., Patel, P., Fahmy, D. F., \& Kaufman, R. R. (2013) Correct Voting Across ThirtyThree Democracies: A Preliminary Analysis. British Journal of Political Science, 44(2), pp. 239-259.

Lau, R. R., \& Redlawsk, D. P. (1997) Voting Correctly. American Political Science Review, 91(3), pp. 585-598.

Lau, R. R., \& Redlawsk, D. P. (2001) Advantages and Disadvantages of Cognitive Heuristics in Political Decision Making. American Journal of Political Science, 45(4), pp. 951-971. 
Lefkofridi, Z., Giger, N., \& Gallego, A. (2014). Electoral Participation in Pursuit of Policy Representation: Ideological Congruence and Voter Turnout. Journal of Elections, Public Opinion \& Parties, 24(3), pp. 291-311 .

McAllister, I. (2007) The Personalization of Politics, in: R. J. Dalton \& H.-D. Klingemann (eds.), The Oxford Handbook of Political Behavior (New York: Oxford University Press), pp. 571-588.

Merrill, S., Grofman, B., \& Adams, J. (2001). Assimilation and contrast effects in voter projections of party locations: Evidence from Norway, France, and the USA. European Journal of Political Research, 40(2), pp. 199-221 .

Miller, W. E., \& Stokes, D. E. (1963) Constituency Influence in Congress in Congress. American Political Science Review, 57(1), pp. 45-56.

Pierce, P. A. (1993) Political Sophistication and the Use of Candidate Traits in Candidate Evaluation. Political Psychology, 14(1), pp. 21-35.

Powell, G. B. (2004) Political Representation in Comparative Politics. Annual Review of Political Science, 7, pp. 273-296.

Rosema, M., \& de Vries, C. (2011). Assessing the Quality of European Democracy: Are Voters Voting Correctly? In M. Rosema, B. Denters, \& K. Aarts (eds.), How Democracy Works (pp. 199-219). Amsterdam: Amsterdam University Press.

Rosema, M., Denters, B., \& Aarts, K. (2011). How Democracy Works: Political Representation and Policy Congruence in Modern Societies. Amsterdam: Amsterdam University Press.

Simas, E. N. (2013) Proximity voting in the 2010 U.S. House elections. Electoral Studies, 32(4), pp. 708-717.

Singh, S. P. (2010) Contextual influences on the decision calculus: A cross-national examination of proximity voting. Electoral Studies, 29(3), pp. 425-434.

Thomassen, J., \& Rosema, M. (2009) Party Identification revisited, in: J. Thomassen (ed), The European Voter: A Comparative Study Of Modern Democracies (Oxford: Oxford University Press), pp. 42-59.

van der Brug, W. (2010). Structural and Ideological Voting in Age Cohorts. West European Politics, 33(3), pp. 586-607. 
Wessels, B. (1999) System Characteristics Matter: Empirical Evidence from Ten Representation Studies, in: P. Esaiasson, R. Herrera, S. Holmberg, R. Pierce, J. Thomassen, \& B. Wessels (eds.) Policy Representation in Western Democracies (New York: Oxford University Press), pp.137-161.

Whiteley, P. F. (2010) Is the party over? The decline of party activism and membership across the democratic world. Party Politics, 17(1), pp. 21-44. 


\section{Tables}

Table 1. Congruence (0-1) means by elections in ascending order

\begin{tabular}{lclc}
\hline Elections & Congruence & Elections & $\begin{array}{c}\text { Congru- } \\
\text { ence }\end{array}$ \\
\hline Estonia 2011 & .601 & Portugal 2009 & .838 \\
South Africa 2009 & .667 & Iceland 2007 & .840 \\
United States 2008 & .687 & Germany 2005 & .842 \\
Mexico 2009 & .688 & Czech Republic 2006 & .844 \\
Brazil 2006 & .706 & Netherlands 2010 & .845 \\
Brazil 2010 & .715 & Finland 2007 & .845 \\
Peru 2011 & .770 & Switzerland 2007 & .850 \\
Mexico 2006 & .778 & Norway 2009 & .849 \\
Poland 2005 & .797 & Canada 2008 & .851 \\
South Korea 2008 & .800 & Denmark 2007 & .851 \\
Austria 2008 & .808 & Norway 2005 & .854 \\
Australia 2007 & .813 & France 2007 & .856 \\
Latvia 2010 & .816 & Czech Republic 2010 & .857 \\
Croatia 2007 & .821 & Netherlands 2006 & .861 \\
Slovakia 2010 & .821 & Finland 2011 & .863 \\
Poland 2007 & .822 & Iceland 2009 & .870 \\
Ireland 2007 & .827 & Germany 2009 & .874 \\
Greece 2009 & .830 & Sweden 2006 & .883 \\
Israel 2006 & .835 & Spain 2008 & .890 \\
New Zealand 2008 & .837 & & \\
\hline Note: Enties are & & & \\
\hline
\end{tabular}

Note: Entries are the mean levels of congruence for every election.

Source: CSES - Module 3, own calculations. 
Table 2. Descriptive variable information

\begin{tabular}{lccccc}
\hline Variables & Min & Max & Mean & $\begin{array}{c}\text { Standard } \\
\text { deviation }\end{array}$ & N \\
\hline Congruence & 0 & 1 & 0.822 & 0.156 & 36,230 \\
Education & 1 & 4 & 2.543 & 0.992 & 36,230 \\
Political knowledge & 0 & 3 & 1.758 & 0.970 & 36,230 \\
Partisan identification & 1 & 3 & 1.622 & 0.749 & 36,230 \\
Gender & 0 & 1 & 0.5 & 0.5 & 36,230 \\
Age & 16 & 100 & 48.094 & 16.819 & 36,230 \\
Disproportionality & .26 & 21.95 & 4.765 & 4.343 & 39 \\
Effective number of electoral & 1.97 & 10.62 & 4.719 & 1.392 & 39 \\
parties (ENEP) & 1.45 & 13.92 & 4.39 & 2.28 & 39 \\
Polarization & & & & &
\end{tabular}

Source : CSES - Module 3, own calculations 
Table 3. Multilevel regression models predicting left-right congruence (0-1)

\begin{tabular}{|c|c|c|c|c|c|}
\hline & $\begin{array}{l}\text { Null } \\
\text { model }\end{array}$ & $\begin{array}{l}\text { Model I } \\
\text { Individual } \\
\text { level variables }\end{array}$ & $\begin{array}{l}\text { Model II } \\
\text { Interaction } \\
\text { partisanship } \\
\text { *knowledge }\end{array}$ & $\begin{array}{l}\text { Model III } \\
\text { Country- } \\
\text { level } \\
\text { variables }\end{array}$ & $\begin{array}{l}\text { Model IV } \\
\text { Cross-level } \\
\text { interaction }\end{array}$ \\
\hline & $\mathrm{b}(\mathrm{SE})$ & b (SE) & $\mathrm{B}(\mathrm{SE})$ & $\mathrm{b}(\mathrm{SE})$ & $b(\mathrm{SE})$ \\
\hline Intercept & $\begin{array}{l}0.813 * * * \\
(-0.103)\end{array}$ & $\begin{array}{l}7.73^{* * *} \\
(0.107)\end{array}$ & $\begin{array}{l}7.77 * * * \\
(0.208)\end{array}$ & $\begin{array}{l}8.49 * * * \\
(0.387)\end{array}$ & $\begin{array}{l}8.37 * * * \\
(0.389)\end{array}$ \\
\hline Individual variables (1st level) & & & & & \\
\hline Political knowledge & & $\begin{array}{l}0.013 * * * \\
(0.001)\end{array}$ & $\begin{array}{l}0.055^{* *} \\
(0.018)\end{array}$ & $\begin{array}{l}0.051^{* *} \\
(0.019)\end{array}$ & $\begin{array}{l}0.121 * * * \\
(0.036)\end{array}$ \\
\hline $\begin{array}{l}\text { Partisan identification } \\
\quad \text { Reference }=\text { No/weak identifier }\end{array}$ & & & & & \\
\hline Somewhat close & & $\begin{array}{l}0.075^{* * *} \\
(0.018)\end{array}$ & $\begin{array}{l}-0.002 \\
(0.025)\end{array}$ & $\begin{array}{l}0.013 \\
(0.009)\end{array}$ & $\begin{array}{l}0.013 \\
(0.023)\end{array}$ \\
\hline Very close identifiers & & $\begin{array}{l}-0.109 * * * \\
(0.021)\end{array}$ & $\begin{array}{l}-0.266^{* * * *} \\
(0.043)\end{array}$ & $\begin{array}{l}-0.247 * * * \\
(0.034)\end{array}$ & $\begin{array}{l}-0.246^{* * *} \\
(0.034\end{array}$ \\
\hline Age & & $\begin{array}{l}-0.001^{*} \\
(0.000)\end{array}$ & $\begin{array}{l}-0.001 * \\
(0.000)\end{array}$ & $\begin{array}{l}-0.001 \\
(0.000)\end{array}$ & $\begin{array}{l}-0.001 \\
(0.006)\end{array}$ \\
\hline Gender & & $\begin{array}{l}-0.039 * * \\
(0.015)\end{array}$ & $\begin{array}{l}-0.039 * * \\
(0.015)\end{array}$ & $\begin{array}{l}-0.053^{* *} \\
(0.016)\end{array}$ & $\begin{array}{l}-0.053^{* *} \\
(0.016)\end{array}$ \\
\hline Educational level & & $\begin{array}{l}0.095 * * * \\
(0.008)\end{array}$ & $\begin{array}{l}0.095 * * * \\
(0.008)\end{array}$ & $\begin{array}{l}0.097 * * * \\
(0.009)\end{array}$ & $\begin{array}{l}0.097 * * * \\
(0.009)\end{array}$ \\
\hline Country-level variables (2nd level) & & & & & \\
\hline Effective number of electoral parties & & & & -0.062 & -0.036 \\
\hline & & & & $(0.055)$ & $(0.055)$ \\
\hline Disproportionality & & & & $\begin{array}{l}0.008 \\
(0.023)\end{array}$ & $\begin{array}{l}0.008 \\
(0.023)\end{array}$ \\
\hline Polarization & & & & $\begin{array}{l}-0.106^{*} \\
(0.041)\end{array}$ & $\begin{array}{l}-0.105^{*} \\
(0.041)\end{array}$ \\
\hline Interaction effects & & & & & \\
\hline ENEP * political knowledge & & & & & $\begin{array}{l}-0.015^{* *} \\
(0.006)\end{array}$ \\
\hline $\begin{array}{l}\text { Party identification (ordinal) * } \\
\text { Political knowledge }\end{array}$ & & & $\begin{array}{l}0.044 * * * \\
(0.011)\end{array}$ & $\begin{array}{l}0.025^{* * *} \\
(0.006)\end{array}$ & $\begin{array}{l}0.025 * * * \\
(0.006)\end{array}$ \\
\hline Variance country-year level & 0.004 & 0.004 & 0.004 & 0.004 & 0.004 \\
\hline ICC & 0.166 & 0.165 & 0.164 & 0.142 & 0.142 \\
\hline
\end{tabular}

Note: Entries are unstandardized b-coefficients from linear multilevel regression models Standard errors (SE) are in parentheses. ${ }^{*} \mathrm{p}<0.05 * * \mathrm{p}<0.01 * * * \mathrm{p}<0.001$.

Source : CSES - Module 3 


\section{Figure}

Figure 1 - Interaction effect on congruence of ENEP and political knowledge

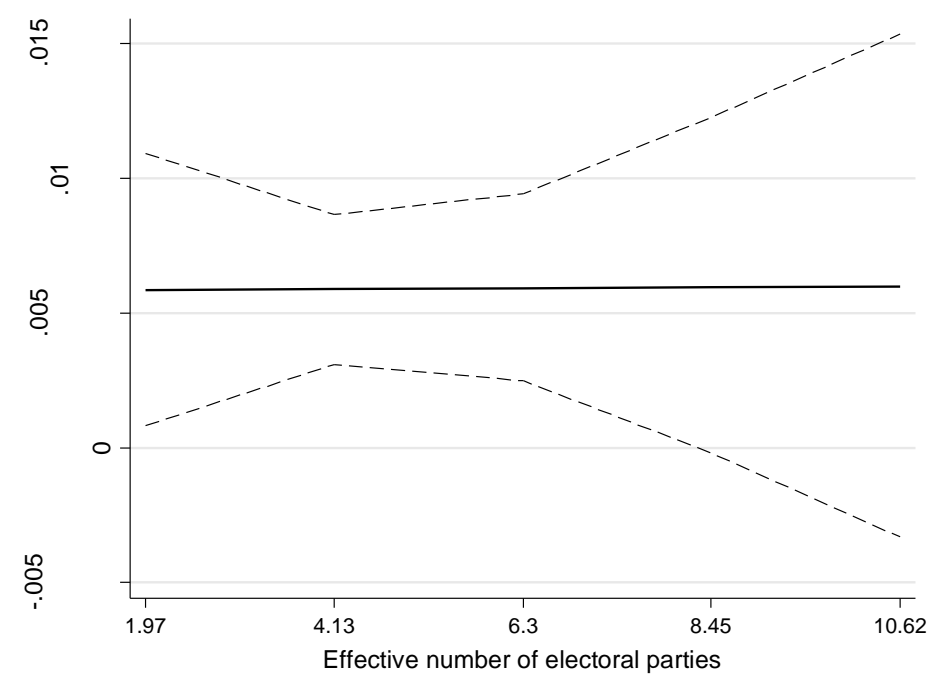




\section{Appendix}

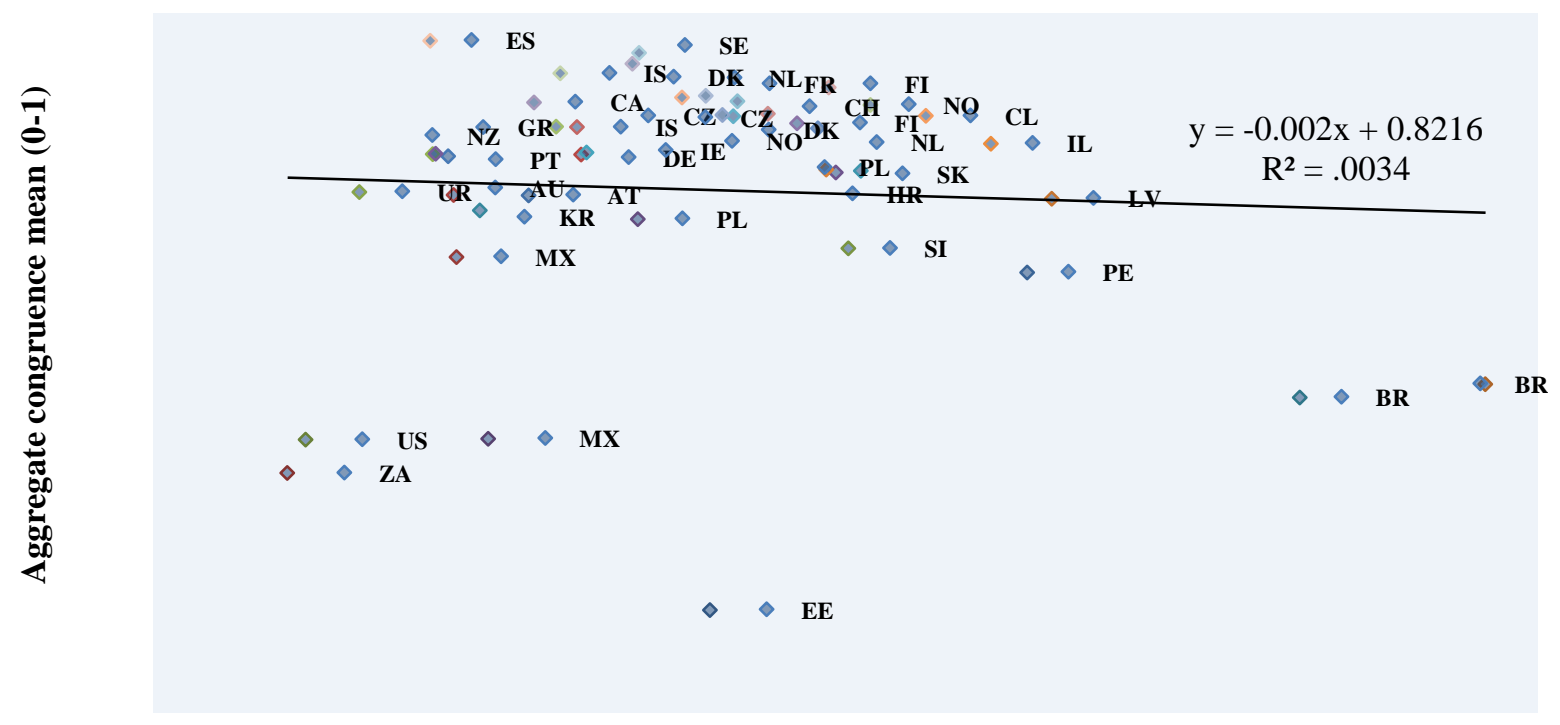

Effective number of electoral parties (ENEP)

Appendix 1. Bivariate relation between mean left-right congruence and the effective number of electoral parties (ENEP)

Source: CSES - Module 3 (own calculations) 